\title{
Calvinism, Proslavery and James Albert Ukawsaw Gronniosaw
}

In the autobiography of James Albert Ukawsaw Gronniosaw, the first black author to be published in Britain, slavery was represented at best neutrally and at worst as spiritually and socially beneficial. Re-reading Gronniosaw's Narrative in the context of the Calvinist and Dutch Reformed confessional networks facilitating its composition and publication, enables us to understand how and why a former slave would produce a text apparently advocating proslavery ideology. Gronniosaw's case demonstrates that black intellectuals, far from being solely concerned with abolitionism, participated in a broad array of political, religious and social movements during the eighteenth century, occasionally even those that supported slavery.

Keywords: Gronniosaw; Hastings; Huntingdon; Whitefield; Frelinghuysen; Wesley; proslavery; Calvinism; Calvinist; Methodist; Methodism; religion; black authors

Subject classification codes: N/A

In 1772, A Narrative of the Most Remarkable Particulars in the Life of James Albert Ukawsaw Gronniosaw became the first text by a black author to be published in Britain. ${ }^{1}$ It was the second to be published in the English language after Briton Hammon's pamphlet-sized Narrative appeared in Boston in $1760 .^{2}$ Unlike Hammon's text, elements of Gronniosaw's autobiography echoed through much of the writing produced by black people during the period of British abolitionism. This fact alone has earned Gronniosaw's Narrative a place in most modern anthologies of early black Atlantic writing. ${ }^{3}$ Yet, even within the comparatively narrow readership of historians of slavery and its abolition, the text and its author remain obscure in relation to their successors, notably Ottobah Cugoano and Olaudah Equiano. ${ }^{4}$ The reasons for this are not instantly obvious, given the significance of the Narrative. It initiated an entirely new corpus of literature about slavery, written by formerly enslaved people and their 
descendants. Some of these authors have rightly attained the degree of attention they deserve. Equiano, for example, has been the subject of two modern scholarly biographies (with a third currently being written), and in 1996 a dedicated Equiano Society was formed in London to 'publicise and celebrate' his work. ${ }^{5}$ All of this suggests ongoing scholarly and popular interest in early black British writing. Yet the author who first introduced such a concept remains in relative obscurity.

One explanation is that the Narrative, unlike its more famous successors, had limited direct impact on the movement to abolish the slave trade in Britain. When the text was published in 1772 , there was little political impetus behind the occasional objections to slavery raised by the Quakers and other religious groups. Even in the aftermath of the famous Mansfield ruling of 1772, few foresaw the nation's withdrawal and suppression of the slave trade within a mere forty-five years. By contrast, when Cugoano and Equiano's texts were published in the late 1780s, they contributed to a political environment in which abolition was already very much on the agenda, and as such they were able to be much more critical of Britain's involvement in the 'evil and wicked traffic in the slavery of the human species' than Gronniosaw. ${ }^{6}$

Indeed, the Narrative's 'tone of obsequious humility' (as Paul Edwards and David Dabydeen phrase it) towards white slave owners threatens to disrupt the historiographical narrative of black resistance to slavery. ${ }^{7}$ It is not the intention of this article to suggest that slave resistance or black opposition to slavery has in any way been overstated. Historically, quite the opposite is true. ${ }^{8}$ But in the case of Gronniosaw's Narrative, slavery was presented at best neutrally and at worst as socially and spiritually beneficial for the enslaved. The existence of proslavery black writing perhaps represents an unwelcome complication in a sensitive and already-complicated historical discussion. Yet to focus solely on that early black literature which took 
abolition as its primary directive is to flatten discussion of the diverse roles played by black intellectuals within eighteenth-century transatlantic social networks, societies and in society at large. It falsely implies that black authors socially (or indeed ideologically) unconnected to the broader abolitionist movement operated in a social vacuum and wrote without outside influences. Even for those interested in early black literature solely for its treatment of slavery and abolition, an understanding of the specific social contexts surrounding the publication of these texts can yield important new interpretations. An investigation into Gronniosaw's life, personal relationships and the circumstances surrounding the Narrative's publication suggests that black writing in the eighteenth century, like all writing, was influenced by a number of factors beyond the author's memory and imagination. In Gronniosaw's case, the author's relationship to evangelical Calvinism and its social networks profoundly affected his depiction of slavery.

The Narrative was published first and foremost as a Calvinist devotional autobiography, at a time when British abolitionism was still in its formative stages. Its discussion of slavery was incidental to its primary function of promoting Calvinism over other forms of Christian worship, particularly the increasingly popular rival sect of Arminian Methodists headed by John and Charles Wesley. A key disparity between Calvinism and Arminianism was that the latter demanded corporeal freedom to achieve salvation while the former did not, leading to a dispute over the moral rectitude of slaveholding. ${ }^{9}$ Calvinists maintained that enslaving non-Christian Africans was beneficial for them as it brought them to God, while Arminians argued that curtailing slaves' corporeal freedom restricted their ability to embrace Christianity. Gronniosaw was indoctrinated into a Calvinist perspective on slavery and spiritual freedom while still enslaved in America. Moreover, the publishing and distribution network of the 
Narrative (not to mention Gronniosaw's amanuensis) were all Calvinists, and the individuals upon whom he and his family financially relied, almost without exception, had some investment in slavery. This is especially true of the mater familias of eighteenth-century British Calvinism and dedicatee of the autobiography Selina Hastings, who had inherited a Georgia plantation and over one hundred slaves from Gronniosaw's other major patron George Whitefield. As Gronniosaw's literacy in English was limited, the text was transcribed for him, almost certainly by Hastings' obsequious admirer Mary Marlow. Hastings' cousin Walter Shirley even wrote the preface. In its implicit defence of slavery as a route to Calvinist Christianity and therefore freedom from sin, the Narrative reflected the religio-political and financial interests of most of the people involved in its publication - and none more so than Hastings.

What follows is an interpretive analysis of the Narrative's representation of its nominal author's life in Africa, America and Britain, understood in the context of the Calvinist proslavery network responsible for its publication and informed by historical and biographical detail not mentioned in the text itself. Drawing together a body of new manuscript evidence on Gronniosaw, such as his correspondence with Hastings and the baptism records of his children, gives an insight into the relationships which directed the physical and spiritual courses of his life. These sources help us to understand how and why a formerly enslaved author came to produce a text advocating a proslavery ideology. Additionally, drawing from the small body of existing criticism and historiography on the Narrative allows, for the first time, a reading which takes into account the proslavery intentions of those who sent it into the public domain. The version of Gronniosaw's life we are left with illustrates how early black writers engaged 
with interests well beyond the movement for abolition, and sometimes even came directly into conflict with it.

\section{Gronniosaw in Africa}

There are a number of important details about Gronniosaw's life in Africa which do not appear in the Narrative, either because he himself had forgotten them or because they were not recorded by his amanuensis. Firstly, the region of Borno was predominately Muslim, yet Gronniosaw described a non-specific, pagan local religiosity in which 'the sun, moon and stars' were 'the objects of our worship'. ${ }^{10}$ But as members of the Borno social elite, his family would have to have practised Islam. ${ }^{11}$ With this in mind, it is easy to identify the Islamic worship practises Gronniosaw participated in during his childhood. For example, he recounts the salah in the following terms:

I rose, as our custom is, about three o'clock, (as we are obliged to be at our place of worship an hour before the sun rise) we say nothing in our worship, but continue on our knees with our hands held up, observing a strict silence till the sun is at a certain height ... when, at a certain sign by the priest, we get up (our duty being over) and disperse to our different houses. ${ }^{12}$

Gronniosaw's suggestion that celestial bodies formed the focus of this ritual probably stemmed from the prescribed times for the salah coinciding with the progress of the day. 
Jennifer Harris has suggested that Gronniosaw purposefully concealed his own knowledge of Islam in order to satisfy 'European desires to be assured of their evident superiority' over Africans, instead painting himself as a 'naïve boy from the backwoods. ${ }^{, 13}$ If this was indeed Gronniosaw's intention, then he must also have consciously underrepresented the size and importance of his home region in the local economy. Serving as a centre of trans-Saharan trade, Borno had been an established Muslim enclave in central Africa for almost 700 years, trading with Egypt, Turkey and other North African countries in commodities such as salt, ivory and slaves. ${ }^{14}$ If Gronniosaw's grandfather was 'the reigning king' as he claimed, his father would have occupied the social status of the Kogunawa, an administrative stratum of Borno society, brokering much of the trade in the region. ${ }^{15}$ In other words, it is quite possible that Gronniosaw's family were themselves involved in some way in the buying and selling of slaves, though if this was the case, they operated in an entirely separate system to the one in he himself was transported.

How does this chime with the fact that Gronniosaw's Narrative was published as a Calvinist devotional? Familiarity with the principal tenet of Calvinism is necessary here to understand the propagandistic character of this early section of the Narrative. Essentially, the Calvinist concept of predestination held that a divinely-appointed 'elect' were preselected by God for entry to heaven, regardless of their earthly actions. ${ }^{16}$ Gronniosaw's text actively supported this notion by representing him as having an innate understanding of monotheistic omnipotence from childhood, coupled with a rejection of alternative belief structures:

My dear mother, says I, pray tell me who is the GREAT MAN of POWER that makes the thunder? She said, there was no power but the 
sun, moon and stars; that they made all our country. - I then enquired how all our people came? She answered me, from one another; and so carried me to many generations back. - Then says I, who made the First Man? and who made the first Cow, the first Lyon, and where does the fly come from, as no one can make him? ${ }^{17}$

This was a striking scene since we know that Gronniosaw's mother, as a member of the Borno social elite, was almost certainly Muslim. ${ }^{18}$ But the utility of withholding this information, in terms of the Narrative's status as denominational propaganda, is easy to recognise. Gronniosaw was established in his status as spiritual elect par excellence at this early stage of the text through his innate rejection of pagan belief structures. Understanding Gronniosaw to have been raised in a monotheistic tradition would have somewhat disrupted the Calvinist predestination narrative serviced by his supposedly (super)natural intuition of an Abrahamic God in the midst of such (however fictional) idolatry. As Harris suggests, the representation of Borno belief structures in the Narrative represented a kind of mythmaking about Gronniosaw's origins, playing up to a British readership's suppositions about the spiritual deprivation of African peoples. However, in her haste to assign to him some kind of abolitionist credence, she fails to recognise that this rhetorical strategy was inherited from the proslavery tradition of his Calvinist antecedents, which will be discussed in detail shortly. ${ }^{19}$ In this context, the Narrative bore more in common with existing proslavery than emergent antislavery discourses.

More striking still was Gronniosaw's reaction to the invitation that would ultimately lead him into slavery. When invited to the Gold Coast by two strangers, he apparently experienced a 'secret impulse upon my mind which I could not resist that 
seemed to tell me I must go.' ${ }^{20}$ The implication here was that Gronniosaw was fatalistically drawn - predestined, one might say - towards the course of events which ultimately led to his enslavement, and more importantly for the Calvinists publishing and reading the Narrative, his spiritual conversion. It should be borne in mind that it was through the tenet of predestination that Calvinists (in particular Gronniosaw's patrons George Whitefield and Selina Hastings) attempted to justify their own continuing involvement in the slave trade and slavery. As we will see, the question of slavery played an important part in the Calvinist/Arminian theological debates of the 1770s. It is essential, therefore, that the Narrative be understood against this background.

After a 'tedious journey' of 'upwards of a thousand miles', during which he was threatened with death by his kidnappers, Gronniosaw arrived on the Gold Coast. ${ }^{21}$ According to the Narrative, here he was accused by the local 'King' of being a spy for his grandfather, and prepared for ritual beheading, but his stoicism in the face of death moved the King to mercy. ${ }^{22}$ Upon hearing his kidnappers again discuss killing him if he could not be sold into slavery, he rushed into the arms of the next potential buyer, an unnamed Dutch slave trader, shouting 'father, save me.' The captain agreed to buy him, and Gronniosaw was transported to Barbados. ${ }^{23}$

Perhaps unsurprisingly, much of the existing literary criticism of the Narrative has focused on these scenes of intercultural contact and slave-trading on the West African coast. Critics have attempted to decode the figurative elements of Gronniosaw's writing to accommodate it within the canon established by his black literary successors. Helena Woodard, for example, argues that the scene in which Gronniosaw rushes to the Dutch Captain 'blurs the distinction among the Father figure as Saviour, the Father figure as enslaver, and the Father figure as patriarch. ${ }^{24}$ The Narrative did indeed lend a 
personal justification to the familiar 'paternalistic' view of enslavement as protecting Africans from the imagined horrors of paganism. In the words of Christopher Leslie Brown, since it "civilized "savages" and converted heathens to Christianity, slavery could be understood as a positive good' during the mid eighteenth-century. ${ }^{25}$ That the image of a young African boy running scared into the arms of a white slave-trader shouting 'father, save me' appeared in a Calvinist devotional autobiography speaks volumes about how religious people attempted to reconcile slavery with their consciences. The reinforcement of a paternalistic view of the role of the slave trade, nominally composed by a former slave, circumscribed the awkward and, in an Arminian/Calvinist context, contentious question of free will. In the Narrative, the choice facing the young Gronniosaw, and by extension all slaves, was clear: spiritual degradation and death at the hands of an African slave-trader, or salvation and life in the hands of a European one.

Moreover, some sea-sickness which 'wore off' as soon as he 'became more accustomed to the sea' was represented as the worst of Gronniosaw's physical experiences of the notorious Middle Passage. ${ }^{26}$ This depiction was severely at odds with those given later by Equiano and Cugoano, whose visceral accounts of the 'absolutely pestilential' lower decks of slave ships and the abuses committed by the 'dirty filthy sailors' proved such potent weapons in the mobilisation of public sentiment against slavery in the late 1780 s and early $1790 s .{ }^{27}$ Nevertheless, Gronniosaw's middle passage was the scene of the Narrative's arguably most impactful scene, in which a trope was introduced which that reverberated through much of the black writing of the next forty years, in autobiographies published by John Marrant in 1785, Cugoano in 1787, Equiano in 1789 and John Jea, c. $1816 .^{28}$ 
He [the ship's Captain] used to read prayer in public to the ship's crew every Sabbath day; and when first I saw him read, I was never so surprised as when I saw the book talk to my master; for I thought it did, as I observed him to look upon it, and move his lips. - I wished it would do so to me. - As soon as my master had done reading I follow'd him to the place where he put the book, being mightily delighted with it, and when nobody saw me, I put my ear down close upon it, in great hope that it wou'd say something to me; but was very sorry and greatly disappointed when I found it would not speak, this thought immediately presented itself to me, that every body and every thing despis'd me because I was black. ${ }^{29}$

This scene has been discussed most fully by Gates, whose theory of the "trope of the talking book' is perhaps the best-known literary criticism to mention Gronniosaw's Narrative. ${ }^{30}$ Gates goes as far as to suggest that 'this trope of the (non-) Talking Book becomes the central scene of instruction against which this African's autobiography must be read', since it explains both the purpose and significance of Gronniosaw's text. For Gates, the Narrative itself emerged from this moment, since it was 'a text that speaks his face into existence among the authors and texts of the Western tradition'; a tradition which had refused to allow him into dialogue with it on board the Dutch ship, because he was black. ${ }^{31}$

The near-exactness of Marrant, Cugoano, Equiano and Jea's replication of this scene has enabled historians to prove the emergence of a black literary tradition in the latter half of the eighteenth century. Cugoano explicitly referenced Gronniosaw by name as an example of an African benefitting from 'some knowledge of the Christian 
religion. ${ }^{32}$ Eve Bannet, building on Gates' work, has considered the influence of Gronniosaw's autobiography on subsequent black writing, again gravitating towards the work of Cugoano and Equiano. ${ }^{33}$ While Bannet's analysis overstates the impact and availability of Gronniosaw's narrative (for example stating that it was 'certainly more widely available and widely read than either Equiano's or Cugoano's texts' on the sole basis of the number of editions produced), her work underlines the significance of the Narrative in the subsequent tradition of black abolitionist writing. ${ }^{34}$

Yet neither Gates' or Bannet's analyses fully acknowledge the representation of transatlantic slavery in Gronniosaw's Narrative as a medium for spiritual (specifically Calvinist) salvation from the 'benighted parts of the world': that is, the central and west Africa of the popular proslavery imagination. ${ }^{35}$ The episode of the talking book reflected not (or at least not only) on the exclusion of the black man from the Western literary or intellectual traditions, but on the exclusion of the African non-Christian from God's love. This makes more sense when considering the nature of Calvinist evangelism in mid-eighteenth century America, the arena for the 'Great Awakening' of post-Reformation evangelical sentiment. It was into the very epicentre of this movement that Gronniosaw was eventually sold as a slave in the late 1730s, and it was there that his own Calvinist awakening took place.

\section{Gronniosaw in America}

Attempts to reconstruct the main movements of Gronniosaw's life in America, beyond the details presented in the Narrative, have been largely limited to the footnotes and introductions accompanying reprints of his autobiography. The text itself notes that he was bought in Barbados by 'Vanhorn', who took him to New York to work as a 
domestic slave before selling him to 'Mr. Freelandhouse', a 'severe' preacher of the gospel, under whose influence he learned to read and write with a tutor named 'Vanosdore' ${ }^{36}$ As befits a devotional, the text focused on Gronniosaw's spiritual journey towards conversion under 'Freelandhouse' and 'Vanosdore', giving little attention to his specific physical movements. Carretta's entry for Gronniosaw in the Oxford Dictionary of National Biography provides a starting point for something more substantial. Carretta notes, for example, that Gronniosaw's third master 'Mr. Freelandhouse' was in fact the prominent Dutch Reformed Minister Theodorus Jacobus Frelinghuysen, and that his tutor 'Vanosdore' was Frelinghuysen's associate, Peter Van Arsdalen. ${ }^{37}$ We can also identify 'Vanhorn' as Cornelius Van Horne, whose family had used domestic slaves since at least 1703.38 Through such identifications, a meaningful chronology can be tentatively overlaid onto the hazily subjective memories expressed in the Narrative. These details are not merely elucidatory of one individual life. Rather, they illustrate that black slaves were present at the nexus of eighteenth-century American evangelical networks, moving between some of the most powerful Calvinist families in the American colonies.

The Van Horne family was a wealthy slaveholding Dutch dynasty with significant political influence in pre-revolutionary New York. Cornelius Van Horne, Gronniosaw's purchaser, was a 'member of the New Jersey Council' between about 1712 and 1745. He owned 'a large plantation on the Rariton River in Somerset County $\mathrm{N}[\mathrm{ew}] \mathrm{J}[\mathrm{ersey}]$ ' of about 557 acres, where Gronniosaw lived and worked as a teenager. ${ }^{39}$ Like many Dutch people in the New York area, Van Horne was a lifelong member of the Dutch Reformed Church. An offshoot of Calvinism, the Dutch Reformed Church shared with the Countess of Huntingdon's Connexion the central tenet of 
predestination. It was while working for Van Horne during the 1720s that Gronniosaw was first exposed to the concepts of Heaven and Hell by a fellow slave named Old Ned.

One day I had just clean'd the knives for dinner, when one of the maids took one to cut bread and butter with; I was very angry with her, and called upon God to damn her; when this old black man told me I must not say so. I ask'd him why? He replied there was a wicked man call'd the Devil, that liv'd in hell, and would take all that said these words, and put them in the fire and burn them. ${ }^{40}$

When Gronniosaw later heard Van Horne's wife swearing, he asked her to stop because 'there is a black man call' $d$ the Devil that lives in hell, and he will put you in the fire and burn you'. When he told his mistress the name of the slave who had told him about the Devil, the slave was 'tyed up and whipp'd, and never suffered to come into the kitchen with the rest of the servants afterwards. ${ }^{, 41}$ Gronniosaw's addition of the word 'black' to his description of the Devil was obviously significant in that it explicated the young man's anxieties over his exclusion from Christianity, in much the same way as the non-talking book. More pragmatically, it significantly affected his spiritual development in two key ways. Firstly, his guilt - ostensibly over swearing, but we may assume also because of his inadvertent expulsion of Old Ned from domestic slavery into more dangerous field work, and possibly for his own black skin - made him aware of his own unworthiness of God's love, and came to play a significant part in his conversion. Secondly, when Mrs. Van Horne related this story in company, one of the listeners quickly offered to buy Gronniosaw, apparently seeing some potential for his spiritual development. 
Theodorus Jacobus Frelinghuysen was Van Horne's minister, preaching (in Dutch) to various congregations along the Raritan River in Somerset County. Once he had bought Gronniosaw, he arranged for him to be tutored in Calvinist theology by his associate, Peter Van Arsdalen. In between classes, Gronniosaw attended his master's sermons, though he complained that Frelinghuysen 'preached the law so severely, that it made me tremble'. ${ }^{42}$ This was an understandable reaction to Frelinghuysen's fiery millenarian style - his sermons had titles like 'The Miserable End of the Ungodly' and 'The Great Earthquake: Emblem of Judgement on Enemies of the Church.' ${ }^{43}$ Yet Frelinghuysen's theology clearly had a great impact on the young slave's spiritual development, since the Narrative's central conversion scene, written over twenty years after the minister's death c.1747, provided the perfect illustrative example of its provenance. Theologian Joel Beeke sums up Frelinghuysen's doctrine thus: 'Frelinghuysen taught that only those are truly saved who have experienced conversion, which includes $[\ldots]$ not only the knowledge of sin and misery, but also the experience of deliverance in Christ, resulting in a lifestyle of gratitude to God. ${ }^{44}$ Gronniosaw's conversion illustrated each stage of this process, beginning with his awareness of $\sin$ and misery:

I could find no relief, nor the least shadow of comfort; the extreme distress of my mind so affected my health that I continued very ill for three days, and nights [...] I was sensible that there was no way for me to be saved unless I came to Christ, and I could not come to Him: I thought that it was impossible He should receive such a sinner as me. $^{45}$ 
After a period of meditation assisted by Van Arsdalen, Gronniosaw had a physical or psychological experience of salvation, hallucinating a 'light inexpressible dart down from heaven' while chopping wood in a clearing beneath an oak tree. The final criterion of Frelinghuysen's vision for salvation was fulfilled when Gronniosaw ‘blest God for my poverty, that I had no worldly riches or grandeur to draw my heart from him. ${ }^{, 46}$ Frelinghuysen's emphases on the physical experiences of both sin and conversion were given credence by Gronniosaw's three-day illness and subsequent conversion.

Gronniosaw's dual statuses as both 'poor heathen' and slave facilitated a more complete conversion scene, since he was blameless in both his ignorance of the 'true' doctrine of Calvinist theology and his prior failure to act in a Christian way by swearing in the Van Horne household. Simultaneously, Gronniosaw reconciled himself to his own enslavement, declaring that he "would not have changed situations [...] for the whole world' ${ }^{47}$ The Narrative thus exculpated both Frelinghuysen and Gronniosaw's own Calvinist publishing network from moral reproach for their involvement in slavery. After the deaths of Frelinghuysen, his wife and all five of their sons between 1747 and 1753, Gronniosaw decided to travel to England, 'because all those who had visited my master from thence were good,' especially George Whitefield, who was Frelinghuysen's 'particular friend. ${ }^{\text {48 }}$ However, threatened with re-enslavement for debt, he was forced to enlist as a cook aboard a privateer. After several years, he cleared his debt and was swindled out of the remainder of his wages by his debtor. Now determined to find Whitefield in England, Gronniosaw enlisted in the 'twenty eighth regiment of foot', serving in Admiral George Pocock's fleet during the taking of Havana in August 1762. ${ }^{49}$ Here he was discharged, and made his way across the Atlantic first to Spain with the prisoners of war, and then to England, arriving in 1763. 
Whitefield was perhaps the most significant religious and social influence on Gronniosaw and his writing. The evangelical Calvinist first visited Frelinghuysen on 19 November 1739, and again throughout his lengthy tours of the East Coast, 1739-40 and 1744-48. ${ }^{50}$ During this time, the English minister accrued a considerable degree of celebrity across America's east coast. Frelinghuysen invited Whitefield to preach at his meeting-houses, notably at the largest congregation at Six-Mile Run in 1747, and it is likely that the Van Horne family were present on these occasions as well as Gronniosaw himself. ${ }^{51}$ Since he was not treated excessively harshly during his bondage under Frelinghuysen, Whitefield would likely have approved of Gronniosaw's enslavement, especially since Frelinghuysen had been at pains to ensure the boy's conversion to a specifically Calvinistic form of Christianity.

Whitefield took a keen interest in the conversion of black slaves, to the point that 'this consideration, as to us, swallows up all temporal inconveniencies whatsoever.' ${ }^{52}$ The land attached to the orphanage he had founded at Bethesda, Georgia, was staffed by slaves as soon as local legislature definitively allowed it in $1750 .{ }^{53} \mathrm{He}$ complained in 1751 that 'It is plain to a demonstration, that hot countries cannot be cultivated without negroes [...] what a flourishing country might Georgia have been, had the use of them been permitted years ago? ${ }^{54}$ But there an evangelical, as well as financial imperative serviced by slave-ownership, and Whitefield prioritised the conversion of African slaves to Christianity not only over their freedom, but even over their physical well-being. While censuring the harsh treatment of slaves, Whitefield conceded that degradation, subjection and even bodily mutilation were potentially conducive to the slaves' ultimate salvation. On 23 January 1739, for example, he wrote an open letter addressed 'to the [slave-owning] inhabitants of Maryland, Virginia, North and South Carolina', later reprinted in The Daily Advertiser in London, and once again 
in 1740 as a standalone volume. After chiding slave-owners for torturing their slaves with knives and pitch-forks, Whitefield mitigated such behaviour on the basis that it engendered dependence on God for comfort, thus necessitating spiritual conversion:

Your present and past bad usage of them, however ill-designed, may thus far do them good, as to break their wills, increase the sense of their natural misery, and consequently better dispose their minds to accept the redemption wrought out for them, by the death and obedience of Jesus Christ. ${ }^{55}$

Despite this seemingly contradictory stance on the treatment of slaves, it is clear that Whitefield maintained an interest in what he perceived as the spiritual wellbeing of both free and unfree black people in America well into the 1740s, and by the time Gronniosaw left America around 1762, he personally 'had heard him preach often at New York. ${ }^{56}$ This, along with his presence at Whitefield's meetings with Frelinghuysen, formed the basis of a relationship characterised by 'very friendly' but infrequent encounters between Whitefield and Gronniosaw until the former's death in $1770 .{ }^{57}$ According to his will, Whitefield's property at Bethesda, along with his slaves there, passed into the hands of his friend Selina Hastings, who was by that time already a central figure in the British Calvinist movement of which Gronniosaw became a part.

\section{Gronniosaw in Britain}

Whitefield's influence over Gronniosaw extended beyond mere doctrine. When

Gronniosaw finally arrived in Britain around 1763/4, he was repeatedly scammed out of 
his money, leaving him almost destitute by the time he found Whitefield at his tabernacle in Moorfields, London. ${ }^{58}$ Whitefield arranged him some lodgings in Petticoat-lane, where he met his future wife Betty for the first time, working at a loom on the floor above. ${ }^{59}$ A mutual commitment to religious ferventism appears to have formed the basis for their marraige. For example, Gronniosaw particularly approved of the fact that Betty was a member of John Allen's Calvinist meeting (also on Petticoatlane). Their early courtship appears to have consisted chiefly of attending sermons given by the Baptist minister and Whitefield's close friend, Dr. Andrew Gifford. ${ }^{60}$ However, they did not marry quickly; Gronniosaw was first convinced by Whitefield's friends to travel to Amsterdam to give an account of his life and conversion 'before 38 Ministers every Thursday for seven weeks together' ${ }^{61}$ After working as a butler in Amsterdam for around another year, he returned to London, lodging with Gifford while he paid off Betty's debts so that he could marry her between 1765 and $1766 .{ }^{62}$

Betty's minister, John Allen, has been described by Carretta as a 'strict Calvinist pastor' ${ }^{63}$ An examination of his published works, prior to his time serving as minister at Petticoat-lane Church between 1764 and 1767, bears this appraisal out. The most severe share with Frelinghuysen's sermons a distinctive millenarian character, particularly The Nature and Danger of Despising Repeated Reproofs and The Destruction of Sodom Improved, as a Warning to Great Britain, whose titles are the gentlest things about them. ${ }^{64}$ Meanwhile Gronniosaw's relationship with the Baptist minister Gifford was facilitated by Whitefield. Gifford's nominal status as a Baptist should not obscure the fact that his theodicy bore a striking resemblance to Whitefield and Allen's Calvinism, again stressing millenarian adventism, antinomianism and predestination. In 1771, he even edited a new edition of Whitefield's Eighteen Sermons. ${ }^{65}$ As Edwin Cannan and Roger Hayden have put it, Gifford's 'unusual combination of a Calvinist theology with 
evangelical passion', marked him out as a preacher whose style was clearly influenced by Whitefield's 'flaming evangelicalism' ${ }^{66}$ In short, the sermons Gronniosaw heard at Gifford and Allen's tabernacles in London, regardless of their denominational status, would have been distinctly Calvinist in character.

Since Gifford and Allen were so similar in their preaching style, it seems unusual that Gronniosaw and Betty would choose to attend Gifford's sermons when Allen's tabernacle was only a few doors down from their lodgings in Petticoat-lane. This is especially true since Allen was a fully incorporated minister in the Calvinist Church whereas Gifford was merely a Baptist minister with Calvinistic leanings. Gronniosaw even needed to be baptised in order to become part of Gifford's congregation. However, this decision may have been influenced by more than personal preference. In 1729, Philip Yorke and Charles Talbot, the Solicitor and Attorney General respectively, had stated that a slave's status did not change upon entering Britain, and that baptism did not automatically manumit him. However, the Yorke Talbot opinion, while taken as a legitimisation of holding slaves in Britain by the West India interest at the time, was never solemnised since the opinion of the Crown Law Officers did not represent a legal precedent. ${ }^{67}$ The popular notion that former slaves could not be compelled to return to slavery after receiving baptism persisted in British society until at least Gronniosaw's baptism around 1765/6. He had already been threatened with re-enslavement for debt once in New York, and now he found himself destitute of money after clearing Betty's debts. As a free black man in Britain prior to the Mansfield ruling of 1772 , it is reasonable to assume that he did everything possible to anticipate an attempt to have him sold back into slavery.

Indeed, the final passages of the Narrative represent some of the specific challenges faced by black people in Britain during the period, as well as some faced by 
working people in general. The final passages of the Narrative chronicle the financial hardships faced by the growing family - agitated by the prejudices of provincial working-class people against Gronniosaw and his family. Due to Betty's refusal to participate in the Spitalfields Riots of 1769 , she could not find work as a weaver in London. ${ }^{68}$ Gronniosaw moved the family to Colchester where a Quaker merchant referred to as 'Handbarar' had offered him work. When he was discharged in the winter, the family moved to Norwich, where they met with prejudice and 'ill-treatment' from all the locals except a Quaker named 'Henry Gurdney', who helped them pay their rent. When one of their daughters died of a fever, none of the local ministers would consent to burying her, ostensibly 'because she had not been baptised'. Only when Gronniosaw was digging a grave in his garden did the Anglican Parson grudgingly consent to a burial, though 'he did not chuse to read the burial service over her'. Shortly afterwards, the family moved to Kidderminster, where there was a large textile manufactory and, crucially, a good Calvinist minister in Benjamin Fawcett, whom Gronniosaw had read about in 'Baxter's Saints Everlasting Rest.' Fawcett found him some work 'twisting silk and worsted together', and Betty 'by hard labour at the loom' also contributed what she could. The Narrative ends with a description of the family's faith in God, unperturbed by their poverty. ${ }^{69}$

During his travels through provincial England, Gronniosaw appeared to have associated for a time more with Quakers than Calvinists, such as 'Henry Gurdney' [Henry Gurney (1721-1777)] and 'Mr. Handbarar' [Osgood Hanbury, (1731-1784)]. It might be assumed that Gronniosaw shared with these men an interest in antislavery activism, since the Quakers, practically alone among all major transatlantic church movements, had been making a concerted protest against the slave trade since at least the early $1750 \mathrm{~s} .^{70}$ But while this position might have been shared by Gurney, Hanbury 
had inherited his fortune from his father's tobacco plantations in Virginia. In the face of quite significant social pressure from his Quaker acquaintances, Hanbury did not relent in his pursuit of profit from slave industry, and during the American Revolution he actually expanded 'his West Indies interest' to minimise his losses in Virginia. ${ }^{71}$ There was, however, one tenuous, intergenerational link between Gronniosaw and the 'establishment' antislavery movement. Hanbury's proslavery interests were not shared by his grandson, the antislavery campaigner Thomas Fowell Buxton. In May 1807, Fowell Buxton married Hannah Gurney, granddaughter of Gronniosaw's other patron, Henry Gurney. ${ }^{72}$ The former slave Gronniosaw could thus only claim a second-hand association with the rarefied social world of the parliamentary abolitionists, ironically through his employment by that rarest of persons: a slave-owning Quaker.

Gronniosaw did not live long after the publication of his narrative, but the key events of his life are relatively simple to reconstruct. Understandably, he became very conscientious in having his children baptised. On Christmas Day 1771, Mary Albert (aged six) Edward Albert (aged four) and newborn Samuel Albert were baptised in the Old Independent Meeting House in Kidderminster by Fawcett. ${ }^{73}$ At around the same time, he received a letter and a charitable donation from the most influential and wealthy Calvinist figure of the period, Selina Hastings. On 3 January 1772, he responded. Considering the letter's frequent misspellings and poor grammar, it is safe to assume that Gronniosaw, a novice in written English, did not use an amanuensis as he would to record his autobiography towards the end of the same year. This makes the letter the only extant sample of his handwriting and signature. (fig. 1) In it, he thanked Hastings for her 'favour', which 'arrived by Mr. Newbon the studant' at 'a time of great necesity,' and explained that he had just returned from 'Mrs. Marlowe's' in nearby Leominster, 'were I was shewed kindness to from my Christian friends. ${ }^{74}$ At some 
point over the following twelve months, the Calvinist minister Walter Shirley met with Gronniosaw, finding him of 'an amiable and tender disposition. ${ }^{975}$ On 25 June 1774, Gronniosaw's fifth child, James Albert Jnr., was baptised, again by Fawcett. ${ }^{76}$ The family moved once more, to Chester, where Gronniosaw died on 5 October 1775 . His short obituary in the London Evening Post recorded him as 'an African Prince of Zaara. ${ }^{77}$

[Figure1.tiff]

The social connections on which Gronniosaw came to rely during the last years of his life all led back to Hastings. When Whitefield died in 1770 , she became the bestknown and most influential Calvinist in Britain. She invested hundreds of thousands of pounds in setting up Calvinist chapels all over Britain, as well as a theological college in Trevecca, Brecknockshire. This level of financial outlay brought her significant social influence with practically every practising Calvinist in the country, including many of Gronniosaw's patrons and friends. Benjamin Fawcett, the minister who baptised Gronniosaw's children, was a regular correspondent with Hastings - it was upon his suit that she decided to build a Calvinist chapel in Kidderminster in $1774 .{ }^{78}$ The 'Mrs. Marlowe' to whom Gronniosaw had alluded in his letter was Mary Marlow, a regular and obsequious correspondent of Hastings' ${ }^{79}$ Marlow, or one of her daughters, almost certainly acted as amanuensis for Gronniosaw's Narrative, ensuring that the written text was inflected as Hastings would want. Similarly, 'Mr. Newbon' was Mr. Newben, a student at Hastings' Trevecca College whose studies were delayed by years because of his constantly running his mistress' errands. ${ }^{80}$ Walter Shirley, who wrote the preface to the Narrative, was Hastings' cousin and the chief lieutenant in her expanding 
connection during the 1760s and 70s. Crucially, Shirley was 'at the forefront of the conflict with the Wesleyans. ${ }^{81}$ Even Gronniosaw's move to Chester in 1774 brought him closer to the consolidated base of Hastings' influence at Trevecca.

Gronniosaw's 'subdued stance on slavery', as Helena Woodard puts it, is less surprising in this context. Hastings followed Whitefield's lead on the issue of slavery. While she did not travel as regularly to America, her financial commitment to the institution was greater. She inherited Whitefield's large plantation and orphanage at Bethesda, and expanded slaveholding there, even requesting that 'a woman-slave' be named 'SELINA, after me. ${ }^{82}$ Yet, like Whitefield, this did not prevent her from taking a keen interest in the spiritual and intellectual output of slaves and former slaves. Not only did she patronise Gronniosaw, paying for the publication of the Narrative, but she also supported the publication of African-born enslaved poet Phillis Wheatley's Poems on Various Subjects the following year. Both Gronniosaw's and Wheatley's texts were dedicated to her. ${ }^{83}$ Hastings' name can also be found among the list of subscribers to Equiano's Interesting Narrative as late as $1789 .{ }^{84}$ In 1774 , she employed a young African preacher named David Margate to attend to her slaves' spiritual needs in Bethesda - echoing Whitefield's practice of preaching spiritual liberation to slaves while perpetuating their physical bondage. ${ }^{85}$

Fawcett, too, had taken a personal interest in the spiritual lives of slaves since at least 1756, when he wrote $A$ Compassionate Address to the Christian Negroes in Virginia. 'Blessed be God,' he wrote, 'your slavery is, I hope, by no means so dangerous to your immortal souls. And the freedom of the soul for eternity is infinitely preferable to the greatest freedom of the body in its outward condition upon Earth.' The text consistently encouraged black slaves to remain passive, 'to submit, yea conscientiously and cheerfully to submit', to 'be always faithful and obedient to your 
earthly masters', to 'be patient, be submissive and obedient, be faithful and true, even when some of your masters are most unkind. ${ }^{86}$ Fawcett's benevolist proslavery ideology, like Whitefield's, necessitated the conflation of racial and religious statuses, inventing an Africa in which corporeal liberty was coterminous with spiritual bondage. This imaginary Africa, christened 'Negroland' in the Compassionate Address, held its inhabitants in an 'unspeakably wretched' civil and religious condition, which

not a little softens the dreadful idea which we are ready to form of their Slavery in America, where the real interest for their present life (if they fall into the hands of humane masters) is much promoted by inuring them to wholesome labour, and their best interest for the life to come may be secured by the glorious light of the Gospel, which, it is hoped, is shining around them. ${ }^{87}$

Fawcett's view was typical of the Calvinist position. For him, just as for Hastings and Whitefield, the enslavement and exploitation of Africans was a benevolent activity, since it delivered them from paganism or the 'delusions of Mahomet' and into the embrace of their church.

Gronniosaw's Narrative, as Walter Shirley stated in his preface to the text, was intended first and foremost to answer the question 'In what manner will God deal with those benighted parts of the world where the Gospel of Jesus Christ hath never reached? ${ }^{88}$ Shirley believed that the text's answer was plain:

[...] he was sold for a slave, and so brought into a Christian land; shall we consider this as the alone effect of a curious and inquisitive 
disposition? [...] Whatever infidels and deists may think; I trust the Christian reader will easily discern an all-wise and omnipotent appointment and direction in these movements. ${ }^{89}$

The reference to 'infidels and deists' in this passage indicated John Wesley's Arminian movement. 'Deists', meaning a person who believes in the existence of God but not in his intervention in earthly matters, was a thinly-veiled reference to the Arminian belief in perfection through the imitation of Christ. This doctrine amounted to a rejection of the Calvinist concept of irresistible grace through predestination. This hermeneutical disagreement formed the basis of the two factions' opposing stances on slavery, as explicated in 1774 by the publication of Wesley's Thoughts on Slavery. ${ }^{90}$ The conflict between Arminians and Calvinists was broader than any single issue, but Hastings' slave-ownership was certainly a contributing factor in the hostility between her and Wesley's connections.

Defamatory pamphlets and inspirational conversion stories circulated within each faction, designed to illustrate the righteousness of one set of beliefs over the other. Gronniosaw's Narrative was sold as one of these. It was printed in Bath, the site of the largest of Hastings' chapels, by Thomas Mills and William Gye, printers of the hymnbooks for the Calvinist connection. ${ }^{91}$ At a mere six pence, it was little more expensive than a newspaper, and was intended to be distributed broadly among the faithful, as an illustrative story of the irresistible nature of God's love. A second Bath edition followed in 1774 , and another in Newport, Rhode Island during the same year to coincide with Hastings' mission there. ${ }^{92}$ In 1779 , a Welsh language edition followed, translated by the eminent Calvinist hymn-writer William Williams Pantycelyn and printed in Aberhonddu, a few miles from Hastings' college at Trevecca. ${ }^{93}$ The Narrative was only 
published where significant Calvinist support already existed. It was printed and distributed through pre-existing Calvinist social networks. Its intended readership was a Calvinist one.

In short, the financiers, amanuensis, producers, printer and readers of Gronniosaw's text were Calvinists seeking to prove that freedom was not necessary to achieve salvation. Many of them derived the bulk of their wealth from the institution. It can hardly be surprising, then, that the Narrative does not call for the abolition of the slave trade as some of its more famous successors would.

\section{Conclusion}

Gronniosaw's Narrative must be understood outwith the traditional 'slave narrative' scholarly paradigm which emphasises the antislavery elements of black authors' writing during the period and pays scant attention to their other myriad concerns. This approach tends to 'flatten' eighteenth century western black writing and philosophy, not only denuding it of much of its nuance but in some cases ignoring its stated intention in furtherance of a more pressing historiographical demand for clarification and testimony. Viewed as an antislavery activist, Gronniosaw was indeed as marginal as the scant historiography surrounding his life and work seems to suggest. If any antislavery or subversive sentiment was encoded in his work, as Jennifer Harris suggests, it was interred deep beneath a complex series of codifications and ironic rhetorical strategies. ${ }^{94}$ This would have been difficult enough if Gronniosaw had written the text himself; with it passing through the moderating hands of an amanuensis and several editors sympathetic to the slave-owning cause, it was near-impossible. Even if he had succeeded in implanting covert abolitionist rhetoric in his autobiography, the readership 
serviced by Hastings' print and distribution network would hardly be inclined to join a barely-emerging political cause championed by their great adversary John Wesley. More to the point, Gronniosaw's social and connectional relationships had been, almost without exception, conducted with individuals whose interests in the slave trade were well-established. At the moment of the Narrative's publication, his family were financially dependent on the good favour of many individuals then being criticised for owning slaves. The first autobiography of a former slave to be published in Britain, through necessity on the part of its author and design on the part of its producers, expressed at most ambivalence towards the slave trade.

Gronniosaw's was a life which highlighted the tentacular growth of the slave trade into many of the institutions, exchanges and debates of the eighteenth century. The Narrative showed that slaves and former slaves participated in and influenced a broad range of political, social and religious concerns well outside the bounds of the debate over slavery. In Gronniosaw's case, the most influential of these circles proved to be the transatlantic Calvinist confessional network because of which he crossed and re-crossed the Atlantic. The text he produced reflected not only their faith, but their financial and political interests in slavery.

For historians seeking to ally Gronniosaw to the emergent antislavery cause of the 1770 s, the most important aspect of his text is that elements of it were repeated elsewhere. His 'subdued' stance on slavery may be awkward for those hoping to underline the undoubtedly central participation of black people in the struggle for abolition, but his work underpinned and resonated throughout subsequent writing by African-born people in the eighteenth century. By attempting to understand why he embraced a theology which assumed his enslavement was beneficial to him, we can gain a clearer understanding of the true political and religious scope of early black 
writing. For this, if no other reason, Gronniosaw deserves a greater degree of recognition and scholarly attention than has hitherto been afforded him.

\section{Acknowledgements}

I am extremely grateful to Douglas Hamilton, Nick Evans and Jessica Moody for their thoughts and comments on various drafts of this article. Thanks are also due to Peter Nockles at the John Rylands Library, Manchester and Helen Weller at Westminster College, Cambridge for their invaluable assistance and apparently inexhaustible patience.

\section{Notes}

${ }^{1}$ Ukawsaw Gronniosaw, A Narrative of the Most Remarkable Particulars in the Life of James Albert Ukawsaw Gronniosaw (Bath: T. Mills and W. Gye, 1772)

${ }^{2}$ Briton Hammon, Narrative of the Uncommon Sufferings and Surprizing Deliverance of Britton Hammon, A Negro Man (Boston MA: J. Green and J. Russell, 1760)

${ }^{3}$ See Paul Edwards and David Dabydeen (eds.), Black Writers in Britain 1760-1890 (Edinburgh: Edinburgh University Press, 1991), 7-23 (Abridged); Adam Potkay and Sandra Burr, Black Writers of the $18^{\text {th }}$ Century: Living the New Exodus in England and America (New York: Palgrave MacMillan, 1995), 24-67; Vincent Carretta (ed.), Unchained Voices: An Anthology of Black Authors in the English-Speaking World of the $18^{\text {th }}$ Century (Lexington KT: University Press of Kentucky, 1996) 32-58; Henry Louis Gates Jnr., Pioneers of the Black Atlantic: Five Slave Narratives from the Enlightenment (Washington: Counterpoint, 1998), 31-61

${ }^{4}$ Studies into Gronniosaw are often contained within introductions and footnotes to reproductions of his text. See Edwards and Dabydeen (eds.), Black Writers in Britain 17601890, 7-8; Potkay and Burr, Black Writers of the $18^{\text {th }}$ Century: Living the New Exodus in England and America, 24; Carretta (ed.), Unchained Voices 55-58. The only full-length studies currently available which go beyond repetition of details found in the Narrative itself are: Jennifer Harris, 'Seeing the Light: Re-Reading James Albert Ukawsaw Gronniosaw', English Language Notes 42 no.4 (2004), 43-57; Helena Woodard, African-British Writings in the Eighteenth Century: The Politics of Race and Reason, (Westport CT: Greenwood, 1999) 31-67; Henry Gates, The Signifying Monkey: A Theory of African-American Literary Criticism (Oxford: Oxford University Press, 1988), 127-170 
${ }^{5}$ Vincent Carretta, Equiano, the African: Biography of a Self-Made Man (Athens, GA: University of Georgia Press, 2005); James Walvin, An African's Life: The Life and Times of Olaudah Equiano, 1745-1797 (London: Continuum, 1998); 'The Equiano Society' [Online] Available from: http://www.equiano.net/society.html (Accessed 30/08/2013)

${ }^{6}$ Ottobah Cugoano, Thoughts and Sentiments on the Evil and Wicked Traffic of the Slavery and Commerce of the Human Species (London: [N.P.], 1787)

${ }^{7}$ Edwards and Dabydeen, Black Writers in Britain, 7

${ }^{8}$ Beginning with Thomas Clarkson's History of the Rise, Progress and Abolition of the African Slave Trade in 1808, nineteenth and twentieth-century British histories of abolition generally emphasised the role of white parliamentary abolitionists like William Wilberforce and Thomas Fowell Buxton while condemning or ignoring slave resistance and the contribution of black abolitionists in Britain and elsewhere. More recent research has shown that slave resistance was far more consistent and widespread in the British colonies than had been assumed. See, for example: Michael Craton, Testing the Chains: Resistance to Slavery in the British West Indies (New York: Cornell University Press, 1982); Richard Hart, Slaves Who Abolished Slavery: Blacks in Rebellion (Kingston: University of the West Indies, 1985); Gelien Matthews, Caribbean Slave Revolts and the British Abolition Movement (Baton Rouge, 2006); Seymour Drescher and Pieter C. Emmer (eds.): Who Abolished Slavery? Slave Revolts and Abolitionism (Oxford: Oxford University Press, 2010)

${ }^{9}$ See, for example, David Hempton, 'Popular Evangelicalism and the Shaping of British Moral Sensibilities, 1770-1840', in Donald Yerxa (ed.), British Abolitionism and the Question of Moral Progress in History (Colombia SC: University of South Carolina Press, 2012), 58-80; John Saillant, 'Slavery and Divine Providence in New England Calvinism: The New Divinity and a Black Protest, 1775-1805', The New England Quarterly, 68:4 (1995), 584608; Boyd Stanley Schlenther, Queen of the Methodists: The Countess of Huntingdon and the Eighteenth-Century Crisis of Faith and Society (Durham: Durham Academic Press, 1997), esp. 87-91

${ }^{10}$ Ibid., 1

${ }^{11}$ Lovejoy, Ecology and Ethnography of Muslim Trade in West Africa, 39-87

${ }^{12}$ Ibid., 2

${ }^{13}$ Jennifer Harris was the first to recognise this ritual as the salah. Jennifer Harris, 'Seeing the Light', 45-46

${ }^{14}$ Lovejoy, Salt of the Desert Sun, 191-200; Anne Haour, 'The Early Medieval Slave Trade of the Central Sahel: Archaeological and Historical Considerations' in Paul Lane and Kevin MacDonald (eds.), Slavery in Africa: Archaeology and Memory (Oxford: Oxford University Press, 2011), 68-70

${ }^{15}$ Harris, 'Seeing the Light', 45

${ }^{16}$ David Carter, 'Calvinism' in John Vickers (ed.), Dictionary of Methodism in Britain and Ireland (London: Epworth Press, 2000)

${ }^{17}$ Gronniosaw, Narrative, 4

${ }^{18}$ Harris, 'Seeing the Light'; Lovejoy, Salt of the Desert Sun, 191-200; Lovejoy, Ecology and Ethnography, 39-86

${ }^{19}$ See, for example, Benjamin Fawcett, A Compassionate Address to the Christian Negroes in Virginia (London: J. Eddowes and J, Cotton, 1756); George Whitefield, The Works of George Whitefield, 7 vols. (London: Edward and Charles Dilly, 1771-2), ii, 402-406; Jacobus Capitein, The Agony of Asar: A Thesis on Slavery, trans. Grant Parker (Princeton: Markus Wiener, 2010)

${ }^{20}$ Gronniosaw, Narrative, 5

${ }^{21}$ Ibid., 5-7

${ }^{22}$ Ibid., 7-9

${ }^{23}$ Ibid., 9-10

${ }^{24}$ Helena Woodard, African-British Writings in the Eighteenth Century, 34 
${ }^{25}$ Christopher Leslie Brown, Moral Capital: Foundations of British Abolitionism (Chapel Hill: University of North Carolina Press, 2006), 58

${ }^{26}$ Gronniosaw, Narrative, 10

${ }^{27}$ Olaudah Equiano, The Interesting Narrative of the Life of Olaudah Equiano, or Gustavus Vassa, the African, 2 vols. (London: N.P., 1789) i.,79; Ottobah Cugoano, Thoughts and Sentiments on the Evil and Wicked Traffic of the Slavery and Commerce of the Human Species (London: N.P., 1787), 10

${ }^{28}$ John Marrant, A Narrative of the Lord's Wonderful dealings with John Marrant (London: R. Hawes, 1785); Cugoano, Thoughts and Sentiments; Equiano, The Interesting Narrative, Jea, John, The Life, History and Unparalleled Sufferings of John Jea, The African Preacher (Portsea: John Williams, [c.1816])

${ }^{29}$ Gronniosaw, Narrative, 10

${ }^{30}$ Gates, The Signifying Monkey, 127-170

31 ibid., $137-8$

${ }^{32}$ Cugoano, Thoughts and Sentiments, 22

${ }^{33}$ Eve Bannet, Transatlantic Stories and the History of Reading, 1720-1810: Migrant Fictions (Cambridge: Cambridge University Press, 2011), 139-158.

${ }^{34}$ Bannet, Transatlantic Stories, 140

35 'benighted parts of the world': Walter Shirley, 'Preface' in Gronniosaw, Narrative, i

${ }^{36}$ Gronniosaw, Narrative, 10-12

${ }^{37}$ See Vincent Carretta , 'Ukawsaw Gronniosaw, (b. 1710x14 d. after 1772)' in $O D N B$

${ }^{38}$ C. S. Williams, Jan Cornelius Van Horne and his Descendants (New York: C. S. Williams, 1912), 7-12

${ }^{39}$ C. S. Williams, Jan Cornelius Van Horne and his Descendants (New York: C. S. Williams, 1912), 7-12

${ }^{40}$ Gronniosaw, Narrative, 11

${ }^{41}$ Ibid.

${ }^{42}$ Ibid., 14

${ }^{43}$ Theodorus Jacobus Frelinghuysen, Forerunner of the Great Awakening: The Sermons of Theodorus Jacobus Frelinghuysen, ed. and trans. Joel Beeke (Grand Rapids: William Eerdman, 2000)

${ }^{44}$ Joel Beeke, 'Introduction', in Frelinghuysen, Forerunner of the Great Awakening, xiv

${ }^{45}$ Gronniosaw, Narrative, 16

${ }^{46}$ Ibid., 18

${ }^{47}$ Ibid.

${ }^{48}$ Ibid., 20

${ }^{49}$ Ibid., 20-24

${ }^{50}$ Schlenther, Boyd Stanley; 'Whitefield, George (1714-1770)' in $O D N B$

${ }^{51}$ Tyerman, Luke; The Life of the Rev. George Whitefield, 2 vols. (London: Hodder and Stoughton, 1890), i, 331

52 ibid, 405

${ }^{53}$ For a detailed examination of Georgian slavery legislation during the 1740s, see Betty Wood, Slavery in Colonial Georgia, 1730-1775 (Athens GA: University of Georgia Press, 1984), 74-88

${ }^{54}$ Whitefield, George; Works of George Whitefield, ii, 404

${ }^{55}$ Whitefield, A Collection of Papers, 9

${ }^{56}$ Gronniosaw, Narrative, 23

${ }^{57}$ Ibid., 26

${ }^{58}$ Ibid.

${ }^{59}$ Ibid., 26-27

${ }^{60}$ Ibid., 27

${ }^{61}$ Ibid., 28 
${ }^{62}$ Ibid., 29-30

${ }^{63}$ Carretta, Unchained Voices, 57 n.95

${ }^{64}$ John Allen, The Nature and Danger of Despising Repeated Reproofs (London: J. Noon and R. Hett, 1750); John Allen, The Destruction of Sodom Improved, as a Warning to Great Britain (London: A. Millar, 1756)

${ }^{65}$ For an example of Gifford's millenarianism, antinomianism and specifically an exploration of the concept of divine pre-ordination, all of which are core Calvinist creeds, see Gifford, Andrew; A sermon in commemoration of the great storm, commonly called the high wind, in the year 1703 (London: A. Ward, 1733); Whitefield, George; Eighteen Sermons (London: J. Gurney, 1771)

${ }^{66}$ Edwin Cannan, rev. Roger Hayden; "Gifford, Andrew (1700-1784)", in ODNB

${ }^{67}$ See Travis Glasson, "'Baptism doth not bestow Freedom”: Missionary Anglicanism, Slavery and the Yorke-Talbot Opinion, 1701-30', William and Mary Quarterly 67 no.2 (2010) 279318; Woodard, African-British Writings in the Eighteenth Century, 39-42

${ }^{68}$ See Peter Linebaugh, The London Hanged: Crime and Civil Society in the Eighteenth Century (London: Allen Lane, 1991), 256-87

${ }^{69}$ Gronniosaw, Narrative, 30-39

${ }^{70}$ Quaker antislavery motions began long before an official line was established. See Brycchan Carey, From Peace to Freedom: Quaker Rhetoric and the Birth of American Antislavery, 1657-1761 (New Haven: Yale University Press, 2012), esp. 177-220

${ }^{71}$ Jacob M. Price, 'Hanbury, John (1700-1758)', in ODNB

${ }^{72}$ Charles Buxton, Memoirs of Sir Thomas Fowell Buxton (London: John Murray, 1848), 19

73 'Kidderminster, Old Meeting House (Independent): Births and Baptisms', The National Archives, London, RG 4/3374

74 'James Albate to Selina Hastings, 3 Jan 1772', Westminster College, Cambridge: Cheshunt Foundation, $\mathrm{F} / 1: 1574$

${ }^{75}$ Gronniosaw, Narrative, iv.

76 'Kidderminster, Old Meeting House (Independent): Births and Baptisms', The National Archives, London, RG 4/3374

${ }^{77}$ London Evening Post, 10 October 1775

${ }^{78}$ Carretta, Unchained Voices, 58 n.129

${ }^{79}$ See 'Mary Marlow to Selina Hastings, 1 Apr 1773', Westminster College, Cambridge: Cheshunt Foundation, F/1:1639

${ }^{80}$ See 'Selina Hastings to Mr. Newben, 3 Jan 1773', John Rylands Library, Manchester: Methodist Archives, 1977/504

${ }^{81}$ Boyd Schlenther, Queen of the Methodists: The Countess of Huntingdon and the EighteenthCentury Crisis of Faith and Society (Durham: Durham Academic Press, 1997), 107-8

82 'John Cosson to Selina Hastings', Westminster College, Cambridge: Cheshunt Foundation A $4 / 2 / 36$

${ }^{83}$ Phillis Wheatley, Poems on Various Subjects, Religious and Moral (Boston: A. Bell, 1773) iii; Gronniosaw, Narrative, ii

${ }^{84}$ Equiano, Interesting Narrative, v. i, p. xii

${ }^{85}$ Schlenther, Queen of the Methodists, 91

${ }^{86}$ Fawcett, Compassionate Address, 11-18

${ }^{87}$ Ibid., 32

${ }^{88}$ Gronniosaw, Narrative, iii

${ }^{89}$ Ibid, iv.

${ }^{90}$ John Wesley, Thoughts on Slavery, (London: R. Hawes, 1774)

${ }^{91}$ e.g. Anon, The Collection of Hymns, sung in the Countess of Huntingdon's Chapel (Bath: T. Mills and W. Gye, 1770)

${ }^{92}$ See Anon, Some Account of the Proceedings at The College of the Right Hon. The Countess of Huntingdon, in Wales (London: n.p., 1772) 
${ }^{93}$ Ukawsaw Gronniosaw, Berr Hanes o'r Pethau Mwyaf Hynod ym Mywyd James Albert Ukawsaw Groniosaw, Tywysog o Affrica, trans. William Williams Pantycelyn (Aberhonddu: E. Evans, 1779)

${ }^{94}$ Harris argues that the Narrative was not 'one which embraces Christianity', but 'one which manipulates Western suppositions and challenges Western superiority' on the grounds that it elided a number of key details regarding Gronniosaw's Islamic upbringing and possible literacy. Harris, 'Seeing the Light', 44 